\title{
Most Preferred Business Banking Product of HDFC Bank in Trichy City
}

\author{
*Uma Rani T. S. ${ }^{1}$, N. Panchanatham ${ }^{2}$ \\ 1MBA Department, J. J. College of Engineering and Technology, Trichy \\ 2Department of Business Administration, Annamalai University, Chidambaram \\ *umasrini07@gmail.com
}

\begin{abstract}
Change is the only constant factor in this dynamic world and banking is not an exception. The changes staring in the face of bankers relates to the fundamental way of banking-which is undergoing rapid transformation in the world of today, in response to the forces of completion productivity and efficiency of operations, reduced operating margins better asset/liability management, risk management, any time and any where banking. The major challenge faced by banks today is to protect the falling margins due to the impact of competition. Another significant impact of banks today is the technology issue. In this study the business banking products of HDFC bank, that best suits the needs of the borrower were analysed. The Customer feels that loans to be obtained require a process that is extremely complicating and time consuming. This calls for an ombudsman setup separately for the domain. The observation and findings of the study have helped to give useful recommendation to bank. The implementation of the suggestion can help to improve strategies and build competencies over that of their competitors. This study has there by helped me by giving exposure into new concepts in today's banking scenario as the interface shifts from service to products. There has also been some insight into competency recognition.
\end{abstract}

Key Words: HDFC Bank, Marketing Strategy, Borrowings, Securities, Business Banking Products

\section{The Industry Profile}

Banks in India can be categorized into non-scheduled banks and scheduled banks. Scheduled banks constitute of commercial banks and co-operative banks. There are about 67,000 branches of Scheduled banks spread across India. During the first phase of financial reforms, there was a nationalization of 14 major banks in 1969. This crucial step led to a shift from Class banking to Mass banking. As far as the present scenario is concerned the banking industry is in a transition phase. The Public Sector Banks (PSBs), which are the foundation of the Indian Banking system account for more than 78 per cent of total banking industry assets. Unfortunately they are burdened with excessive Non Performing assets (NPAs), massive manpower and lack of modern technology. On the other hand the Private Sector Banks in India are witnessing immense progress. They are leaders in Internet banking, mobile banking, phone banking, ATMs. On the other hand the Public Sector Banks are still facing the problem of unhappy employees. There has been a decrease of 20 percent in the employee strength of the private sector in the wake of the Voluntary Retirement Schemes (VRS). As far as foreign banks are concerned they are likely to succeed in India.

\section{The changing paradigm of banking}

Change is the only constant factor in this dynamic world and banking is not an exception. The changes staring in the face of bankers relates to the fundamental way of banking-which is undergoing rapid transformation in the world of today, in response to the forces of completion productivity and efficiency of operations, reduced operating margins better asset/liability management, risk management, any time and any where banking. The major challenge faced by banks today is to protect the falling margins due to the impact of competition. Another significant impact of banks today is the technology issue. There is an imperative need for not mere technology up gradation but also its integration with the general way of functioning of banks to give them an edge in respect of services provided to optimizing the use of funds and building up MIS for decision making and better management of assets and liabilities and risk assumed which in turns have a direct impact on the balance sheet of banks as a whole. Word over, technology has demonstrated potential to change methods of selling marketing, advertising, designing, pricing and distributing financial products of an electronic, self-service product delivery channel. All these changes call for a new, more dynamic, aggressive and challenging work culture to meet the 
demands of customer relationships, product differentiation, brand values, reputation, corporate governance and regulatory prescriptions.

\section{Challenges facing by Indian Banks}

The main challenges facing by Indian banking are the role of financial instrumentation in different phases of the business cycle, the emerging compulsions of the new prudential norms and benchmarking the Indian financial system against international standards and best practices. The need for introduction of new technology in the banking and the importance of skill building and intellectual capital formation in the banking industry are also equal important.

\section{Technology Banking}

Innovation in technology and world-wide revolution in information and communication technology are perceived to be the catalyst of productivity growth. The relationship between IT and Banking is fundamentally symbiotic. It is expected to reduce costs, increase volumes and facilitate customized products. Technology adoption is a dire necessity for the public sector banks to complete with new generation private sector and foreign banks. It is a 'compulsion' rather than a 'choice'. Retention of existing customer is the primary concern of majority of the banks today. The major challenge for banks is to fall in line with the emerging scenario and adopting the require technology to provide stake-of-the-art services to the customers. Introduction of on-line, inter-connected automatic teller machines (ATM), telephone banking, on-line bill payment and Internet banking are some of the high tech facilities. Banks have to provide in order to survive in the competitive scenario. Technology should ultimate results in better customer service, low cost and quick delivery.

\section{The Organization Profile of HDFC}

HDFC Bank was incorporated in August 1994, and, currently has a nationwide network of 761 Branches and 1977 ATM's in 327 Indian towns and cities. The Housing Development Finance Corporation Limited (HDFC) was amongst the first to receive an 'in principle' approval from the Reserve Bank of India (RBI) to set up a bank in the private sector, as part of the RBI's liberalization of the Indian Banking Industry in 1994. The bank was incorporated in August 1994 in the name of 'HDFC Bank Limited', with its registered office in Mumbai, India. HDFC Bank commenced operations as a Scheduled Commercial Bank in January 1995. HDFC Bank began operations in 1995 with a simple mission: to be a "World-class Indian Bank". We realised that only a single-minded focus on product quality and service excellence would help us get there. Today, we are proud to say that we are well on our way towards that goal. It is extremely gratifying that our efforts towards providing customer convenience have been appreciated both nationally and internationally. HDFC Bank recognizes the importance of good corporate governance, which is generally accepted as a key factor in attaining fairness for all stakeholders and achieving organizational efficiency. This Corporate Governance Policy, therefore, is established to provide a direction and framework for managing and monitoring the bank in accordance with the principles of good corporate governance.

The objectives of the study are:

- To know the marketing strategies adopted by HDFC Banks to sell its products.

- To evaluate the performance of various business banking products offered by HDFC.

- To evaluate and forecast on the genuine customers of HDFC

\section{Market focused or customer focused:}

A market-focused, or customer-focused, organization first determines what its potential customer's desire, and then builds the product or service. Marketing theory and practice is justified in the belief that customers use a product or service because they have a need, or because it provides a perceived benefit. Two major factors of marketing are the recruitment of new customers (acquisition) and the retention and expansion of relationships with existing customers (base management). Once a marketer has converted the prospective buyer, base management marketing takes over. The process for base management shifts the marketer to building a relationship, nurturing the links, enhancing the benefits that sold the buyer in the first place, and improving the product/service continuously to protect the business from competitive encroachments. 


\section{Review of Literature}

Marketing is an ongoing process of planning and executing the marketing mix (Product, Price, Place, Promotion often referred to as the 4 Ps) for products, services or ideas to create exchange between individuals and organizations. Marketing tends to be seen as a creative industry, which includes advertising, distribution and selling. It is also concerned with anticipating the customers' future needs and wants, which are often discovered through market research. Bodla (2005) has made a study a "service quality perception in banks "An Indian perspective". The objective of the study is to examine and measure the quality of services provided by commercial banks in India. Empirical survey is conducted to determine expectation and perception of the quality of services offered by the banks. The scope of this study is restricted to Chandigarh, Delhi and Haryana and the study covers four private sector and four public sector Banks. The SERVQUAL instrument developed by Paramusraman, Zeithmal and Berry (1988) has been used for the measurement of service quality in selected banks. The study reveals that actual delivery of services by both private and public sector banks falls short of expectations of customer on a large majority of the elements of service quality. Never the less private sector is found to have an edge over public sector banks in terms of quality services being offered to customer.

Sureshchandar, Chandrasekharan, Anantharaman and Kamalanabhan (2002) in their study, examined the banks industry in India. The analysis investigated the discrepancies among the various group of banks in India with respect to the total quality service (TQS) dimensions from the perspectives of the management. The result indicated that the 3 groups of banks in India varied significantly. They identified the dimensions that contributed most to the discrimination between the groups. They also computed and analyzed the total quality service indices with respect to the twelve dimensions for the three groups of banks and for banks industry as a whole in order to ascertain level of TQS implementation in the Indian banking scene. The study offered key insights on the criticality of the different TQS dimensions with respect to the banking sector. According to Dibb et al (2001) to formulate a marketing strategy, the marketer identifies and analyses the target market and develops a marketing mix to satisfy individuals in that market. Marketing strategy is best formulated when it reflects the overall direction of the organization and is coordinated with all the company's functional areas. The strategic market planning process is based on an analysis of the broader marketing environment, by which it is very much affected. Marketing environment forces such as legal forces, political forces, technological forces, economic and competitive forces, societal/green forces, and regulatory forces, can place constraints on an organization and possibly influence its overall goals; they also affect the amount and type of resources that a business can acquire.

Implicitly, the strategy requires clear objectives and a focus in line with an organization's corporate goals; the right customers must be targeted more effectively than they are by its competitors, and associated marketing mixes should be developed into marketing programs that successfully implement the marketing strategy (Varadarajan, 1999). The process of strategic market planning yields a marketing strategy that is the framework for a marketing plan. A marketing plan includes the framework and entire set of activities to be performed; it is the written document or blueprint for implementing and controlling an organization's marketing activities. Thus a strategic market plan is not the same as a marketing plan; it is a plan of all aspects of an organization's strategy in the marketplace (Dibb et al., 1996). Porter (1990) quoted that the competitive advantage is achieved through innovation. In its broadest sense this includes both new technologies and new processes. New bases for competing better means of competition new production process and new marketing approaches are all aspects of innovation. Encouraging firms to make major long run innovations is particularly critical. Porter (1990) in another journal cited that company's developing strategies to achieve the competitive advantage would invaluably establish a competitive edge for their country. Weitz and Wensley (1988) defined marketing strategy as an indicator that is specific towards which activities are to be targeted and the types of competitive advantages that are to be developed and exploited.

\section{Research Methodology}

This study attempts to find out the performance of the different products offered by the bank for various businesses. The survey method was adopted for collecting the primary data. Survey research is the systematic gathering of data from respondents through questionnaire. The data for this research was collected by survey techniques using interview method, guided by questionnaire. The method used here is convenient sampling, where the samples are selected based on the convenience of researcher. Sampling 
size is the number of customers to be selected from the universe to constitute the sample. In this study, a sample size of 100 has been chosen. This study was undertaken in Trichy city. The study has used various statistical tools for the analysis of the data. They are percentage analysis, chi-square test.

\section{Analysis and Interpretation}

\section{Results Descriptive Test}

Table 1: Years of existence in industry

\begin{tabular}{lll}
\hline No. of Years & Frequency & Percentage \\
\hline$<1$ & 17 & 17 \\
$01-03$ & 22 & 22 \\
$03-05$ & 13 & 13 \\
$05-07$ & 31 & 31 \\
$>7$ & 17 & 17 \\
Total & 100 & 100 \\
\hline
\end{tabular}

From the above table it is inferred that $17 \%$ of the customers are in business for 1 year, $22 \%$ of the customers are in the business for 1-3 years, 13\% of the customers are in the business for 3-5 years, 31\% of the customers are in the business for 5-7 years and 17\% of the customers are in the business for more than 7 years. So it is concluded that $31 \%$ of the customers are in the business for 5-7 years.

Table 2: Factors to be considered while borrowing

\begin{tabular}{llll}
\hline \multicolumn{1}{c}{ Factors } & Frequency & \multicolumn{1}{c}{ Percentage } \\
\hline Interest rate & 44 & 44 \\
Period of lending & 33 & 33 \\
Documentation procedure & 23 & 23 \\
Total & 100 & 100 \\
\hline
\end{tabular}

From the above table it is inferred that $44 \%$ of the customers consider the interest rate as the main factor for borrowing, $33 \%$ of the customers considered period of lending as the main factor for borrowing and $23 \%$ of the customers considered that documentation procedure is the main factor for borrowing. So it is concluded that $44 \%$ of the customers considered that interest rate is the main factor for borrowing.

Table 3: Range of loan amount availed

\begin{tabular}{lll}
\hline Range of loan (in Crores) & Frequency & Percentage \\
\hline$<1$ & 31 & 31 \\
$01-03$ & 30 & 30 \\
$03-05$ & 29 & 29 \\
$>7$ & 10 & 10 \\
Total & 100 & 100 \\
\hline
\end{tabular}

From the above table it is observed that $31 \%$ of the customers availed loan less than 1 crore, $30 \%$ of the customers availed loan between 1-3 crores, $29 \%$ of the customers availed loan between 3-5 crores and $10 \%$ of customers availed loan above 7 crores. It is concluded that $31 \%$ of the customers availed loan below 1 crore. 
Table 4: Type of Security

\begin{tabular}{lll}
\hline Security & Frequency & Percentage \\
\hline Fixed asset & 23 & 23 \\
Stock & 19 & 19 \\
Debtors & 21 & 21 \\
Collateral & 37 & 37 \\
Total & 100 & 100 \\
\hline
\end{tabular}

From the above table it is observed that $23 \%$ of customers chosen fixed asset as a type of security, $19 \%$ of customers chosen debtors as a type of security, $37 \%$ of customers chosen collateral as a type of security. It is concluded that $37 \%$ of customers chosen collateral as a type of security.

Table 5: Collateral security

\begin{tabular}{lll}
\hline Collateral security & Frequency & Percentage \\
\hline Equity shares & 21 & 21 \\
Mutual fund & 19 & 19 \\
LIC policies & 19 & 19 \\
Relief bonds & 13 & 13 \\
Fixed deposits & 28 & 28 \\
Total & 100 & 100 \\
\hline
\end{tabular}

From the above table it is observed that $21 \%$ of the customers prefer equity shares as their collateral security, $19 \%$ of the customers prefer mutual funds as their collateral security, 19\% of the customers prefer LIC polices as their collateral security, 13\% of customers prefer relief bonds as their collateral security and $28 \%$ of customers prefer fixed deposits as their collateral security.

Table 6: Documentation procedure

\begin{tabular}{lll}
\hline Documentation & Frequency & Percentage \\
\hline Very customer friendly & 36 & 36 \\
Customer friendly & 34 & 34 \\
Not customer friendly & 30 & 30 \\
Total & 100 & 100 \\
\hline
\end{tabular}

From the above table it is observed that $36 \%$ of the customers feel that documentation procedure is very customer friendly, $34 \%$ of customers feel that documentation procedure is customer friendly and $30 \%$ of customers feel that documentation procedure not customer friendly. It is concluded that 36\% of customers feel that documentation procedure is very customer friendly. 
Table 7: Credit appraisal

\begin{tabular}{lll}
\hline Credit appraisal & Frequency & Percentage \\
\hline Business appraisal & 31 & 31 \\
Management appraisal & 22 & 22 \\
Financial appraisal & 47 & 47 \\
Total & 100 & 100 \\
\hline
\end{tabular}

From the above table it is observed that $31 \%$ of customers prefer business appraisal as their credit appraisal, $22 \%$ of customers prefer management appraisal as their credit appraisal and $47 \%$ of customers prefer financial appraisal as their credit appraisal. It is concluded that $47 \%$ of customers prefer financial appraisal as their credit appraisal.

\section{Table 8: Level of Satisfaction}

\begin{tabular}{lll}
\hline Satisfaction level & Frequency & Percentage \\
\hline Highly satisfied & 49 & 49 \\
Satisfied & 34 & 34 \\
Somewhat satisfied & 17 & 17 \\
Total & 100 & 100 \\
\hline
\end{tabular}

From the above table it is observed that $49 \%$ of customers are highly satisfied with loan application, $34 \%$ of customers are satisfied with loan application and $17 \%$ of customers are somewhat satisfied with loan application. It is concluded that $49 \%$ of customers are highly satisfied with loan application.

Table 9: Level of Agreement towards needs

\begin{tabular}{lll}
\hline Agreement for statement & Frequency & Percent \\
\hline Agree & 18 & 18 \\
Neutral & 43 & 43 \\
Disagree & 20 & 20 \\
Strongly disagree & 19 & 19 \\
Total & 100 & 100 \\
\hline
\end{tabular}

From the above table it is observed that $18 \%$ of customers agree HDFC suit their needs, $43 \%$ of customers neutral towards HDFC suit their needs, $20 \%$ of customers disagree HDFC suit their needs and $19 \%$ of customers strongly disagree HDFC suit their needs. It is concluded that $43 \%$ of customers neutral towards HDFC suit their needs. 


\section{Results of Chi - Square Test}

Table 10: Types of Loan

\begin{tabular}{lll}
\hline & Observed & Expected \\
\hline Demand loan & 24 & 25 \\
Over draft & 35 & 25 \\
Bills purchasing & 21 & 25 \\
Export & 20 & 25 \\
Total & 100 & \\
\hline
\end{tabular}

Test statistics $\chi_{o}{ }_{0}^{2} 3 \mathrm{df}=5.680$, Expected value $\chi_{\mathrm{e}^{2}} \mathrm{df}=7.815$, since $\chi_{o^{2}} 1 \mathrm{df}<\chi_{\mathrm{e}^{2}} \mathrm{df}$, Null hypothesis "customers will give equal priorities to all types of loan" is accepted. From the above table it is inferred that equal priorities will be given to all types of loans.

Table 11: Purpose of borrowing

\begin{tabular}{lll}
\hline & Expected & Observed \\
\hline Working cap & 47 & 33.3 \\
Cap expenditure & 32 & 33.3 \\
Modernization & 21 & 33.3 \\
Total & 100 & \\
\hline
\end{tabular}

Test statistics $\chi_{o^{2}} 2 \mathrm{df}=10.220$, Expected value $\chi_{\mathrm{e}^{2}} \mathrm{df}=5.991$, since $\chi_{\mathrm{o}^{2}} 2 \mathrm{df}>\chi_{\mathrm{e}^{2}} \mathrm{df}$, Null hypothesis "the various purpose of borrowing by the customers is equally distributed" is rejected. From the above table it is inferred that purpose of borrowing by the customers is not equally distributed and the purpose of loan is for getting working capital requirement.

Table 12: Mode of charging securities

\begin{tabular}{lll}
\hline & Expected & Observed \\
\hline Pledge & 32 & 25 \\
Hypothecation & 35 & 25 \\
Mortgage & 19 & 25 \\
Assignment & 14 & 25 \\
Total & 100 & \\
\hline
\end{tabular}

Test statistics $\chi{ }_{o}{ }^{2} 3 \mathrm{df}=12.24$, Expected value $\chi \mathrm{e}^{2} \mathrm{df}=7.815$, since $\chi_{\mathrm{o}^{2}} 3 \mathrm{df}>\chi_{\mathrm{e}^{2}} \mathrm{df}$, Null hypothesis "customers give equal importance to various mode of charging securities" is rejected. From the above table it is inferred that most of the customer preferred hypothecation as the mode of charging securities 
Table 13: Period of Fund Requirement

\begin{tabular}{lll}
\hline Months & Observed & Expected \\
\hline 60 & 24 & 33.3 \\
12 & 48 & 33.3 \\
Self & 28 & 33.3 \\
Total & 100 & \\
\hline
\end{tabular}

Test statistics $\chi{ }_{o}^{2} 2 \mathrm{df}=9.920$, Expected value $\chi \mathrm{e}^{2} \mathrm{df}=5.991$, since $\chi o^{2} 2 \mathrm{df}>\chi \mathrm{e}^{2} \mathrm{df}$, Null hypothesis "customers give equal priorities to period of fund requirement" is rejected. From the above table it is inferred that most of the customers requisite of their fund in 12 months.

\section{Findings}

The business customers selected the banks on the basis interest rate provided to them, Overdraft facilities provided, Different types of collateral securities used for hypothecation, Depending upon the bank's performance towards loan documentation. Thus on the basis of the service quality and performance of the banks, the customer will select the prompt one. The same was argued by Paramusraman et al (1988), the service quality, as the consumer's comparison between customers' expectations and performance and the service quality is determined by the customer perceptions towards it. Samli \& Frohlich (1992) and Sudesh (2007) said that delivering quality service to customer is one of the ways for banks to respond and compete for success and survival. The customer satisfaction was developed on the basis of a number of scales developed by many authors (Walter, Muller, Helfert \& Ritter, 2003; Fornell, 1992; Ganesan, 1994). The customers are satisfied with the loan performance made by HDFC and also about needs that are satisfied by HDFC bank. Weitz and Wensley (1988) defined marketing strategy as an indicator that is specific towards which activities are to be targeted and the types of competitive advantages that are to be developed and exploited. Here the target group is business persons and the type of competitive advantage adopted by HDFC bank are comfortable inspection of fixed assets, customer friendly documentation procedure, accurate financial appraisal and credit appraisal for loan sanctioning.

\section{Conclusion and Recommendations}

It would be suggested to add some additional factors like customers' loyalty and behavioral intentions of the stake holders in the study area. A confidential interface can be set up for customer. So that they can obtain the required documents online - this in turn scares a lot of time and logistics. The bank must conduct program to throw light of the use of technology required. A through system audit in regular intervals will help to frame better competitive strategies. Documentation procedures can be made more simplified. The debt collection policies must be strengthened to avoid non performing asset. Cross selling of various products like Equity shares, Mutual fund, LIC policies, Relief bonds and Fixed deposits can be increased among the stake holders and their by loan procedure through collateral security can be made more simplified. In the changing and speedy environment HDFC bank must identify and update the expectation of the stake holders and can try to satisfy their maximum needs.

The observation and findings of the study have helped to give useful recommendation to bank. The implementation of the suggestion can help to improve strategies and build competencies over that of their competitors as a straight forward opinion from a sample of customers have been obtained to make observations. This study has there by helped me by giving exposure into new concepts in today's banking scenario as the interface shifts from service to products. There has also been some insight into competency recognition.

\section{Limitations of the Study}

- Sample of the study consisted only on 100 respondents

- Unwillingness of some respondents to provide information is another limitation.

- Findings of the study are influenced by personal bias of the respondents.

- There was a time constraint which disabled a personal interaction with the customers 


\section{References}

Bodla, S. (2005). Service quality perception in banks, An Indian Perspective. Prajnam, 33(4): 321-335.

Dibb, S., Simkin, L., Pride, W. M., and Ferrell, O. C., (2001). Marketing concepts and strategies, Houghton Mifflin, Fourth European Edition.

Dibb, S., Simkin, L., and Bradley, J. (1996). The marketing planning workbook. London, Thomson Learning.

Fornell, C. (1992). A national customer satisfaction barometer: the Swedish experience. Journal of Marketing, 56(1): 6-21.

Ganesan, S. (1994). Determinants of long-term orientation in buyer-seller relationships. Journal of Marketing, 58(2): 1-19.

Parasuraman, A., Zeithaml, V. A., Berry, L. L. (1988). SERVQUAL: a Multiple-item Scale for Measuring Consumer Perceptions of Service Quality. Journal of Retailing. 64(1): 12-40.

Porter, M., (1990a). The Competitive Advantage of Nations. London, The Free Press.

Porter, M. (1990b). The competitive advantage of nations. Harvard Business Review: 68(2): 73-93.

Samli, A. and Frohlich, C. (1992). Service: the competitive edge in banking. Journal of Services Marketing. 6(1):15-22.

Sudesh, P. (2007). Service quality in banks-A study in Haryana and Chandigarh. NICE Journal of Business, 2(1): 55-65.

Sureshchandar, G. S., Chandrasekharan, R., Anantharaman, R. N., Kamalanabhan, T. J. (2002). Managements perception of Total Quality Service in Banking Sector of a Developing Economy- A critical Analysis. The International Journal of Bank Marketing, 20(4): 181-196.

Varadarajan, P. R. (1999). Strategy content and process perspectives revisited. Journal of the Academy of Marketing Science, 27(1): 88-100.

Walter, A., Muller, T. A., Helfert, G. and Ritter, T. (2003). Functions of Industrial Supplier Relationships and Their Impact on Relationship Quality. Industrial Marketing Management, 32(2): 159-169.

Weitz, B. A., and Wensley, R., (1988), Readings in Strategic Marketing, Chicago: The Dryden Press. 